\title{
Seven Linear B Syllabograms of Conventionally Unknown Phonetic Value
}

\author{
Ioannis K. Kenanidis ${ }^{1}$ \& Evangelos C. Papakitsos ${ }^{2}$ \\ ${ }^{1}$ Primary Education Directorate of Kavala, Kavala, Greece \\ ${ }^{2}$ Secondary Education Directorate of Dytiki Attiki, Elefsina, Greece \\ Correspondence: Ioannis K. Kenanidis, Primary Education Directorate of Kavala, Ethnikis Antistaseos 20,65110 \\ Kavala, Greece. E-mail: ioakenanid@sch.gr
}

Received: July 8, 2018; Accepted: August 12, 2018; Published: August 29, 2018

\begin{abstract}
This paper presents seven syllabograms (signs used for Consonant-Vowel [CV] syllables) of the Linear B syllabary that are conventionally considered of unknown phonetic value. This presentation is conducted following the theory of the Cretan Protolinear syllabary as the one that all the Aegean syllabaries evolved from, namely Linear A, Cretan Hieroglyphics, Linear B, cognate to Cypro-Minoan and the Linear Cypriot Greek. It is demonstrated that the phonetic value of each syllabogram corresponds to the Eteocretan name (in a conservative dialect of Sumerian) of the concrete object depicted by each syllabogram. Thus, more light is shed on the linguistic ancestry of the Minoan scripts and the practice followed for their creation.
\end{abstract}

Keywords: Aegean syllabaries, Cretan Protolinear, Linear B, Eteocretan language, Minoan syllabograms

\section{Introduction}

The Aegean syllabaries include five pre-alphabetic signaries used in the Aegean region and Cyprus, documented mostly from the $2^{\text {nd }}$ millennium BCE. Those were the Cretan Hieroglyphic (henceforth $\mathrm{CH}$ ), Linear A (henceforth LA), Linear B (henceforth LB), Cypro-Minoan and the Linear Cypriot Greek (Davis, 2010) in two versions: the Paphian and the non-Paphian. These syllabaries consist of signs that mostly render monosyllabic phonetic values of the Consonant-Vowel (CV) or single Vowel (V) type, with only very rare exceptions (Kenanidis \& Papakitsos, 2017a).

The Linear Cypriot Greek (henceforth LCG) syllabary, used in Cyprus during the $1^{\text {st }}$ millennium BCE, had been the last one to be created and the first one to be deciphered, by the assyriologist George Smith in the $19^{\text {th }}$ century (Steele, 2017). It usually conveys the Arcado-Cypriot dialect of Greek and rarely a local unknown language called "Eteocypriot". The second syllabary that was deciphered, by Ventris (Ventris \& Chadwick, 1953), has been LB (Judson, 2017), conveying the oldest attested dialect of Greek (namely, Mycenaean Greek). The next syllabary that has been in large part deciphered, by Kenanidis (2013), is $\mathrm{CH}$, conveying the Eteocretan language, which is a conservative dialect of Sumerian (Kenanidis, 1992). Note though that CH (Cretan Hieroghlyphic) differs to the other Aegean scripts, as it was used mostly for short labels on seals (Papakitsos \& Kenanidis, 2016) and short invocations on religious artifacts (Kenanidis, 2016; Kenanidis \& Papakitsos, 2017b). LA has not been totally and undoubtedly deciphered, but the available evidence suggests that it conveyed more than one languages, including Semitic/Akkadian, Luwian/Anatolian and Pelasgian (Woudhuizen, 2016). Cypro-Minoan, having yielded a very small amount of text to modern researchers, has not been deciphered yet, but it is the obvious predecessor of LCG.

The decipherment of LB has been applied to 89 syllabograms, although leaving 16 of them that are still considered to be of unknown or very doubtful phonetic value (Hooker, 2011, p. 83). This inability to discover their phonetic value is connected to the hitherto failure and lack of interest by archaeologists and linguists to recognize what exactly was depicted by each syllabogram and which was the language behind their creation. As to the latter issue, it has been attested that all the Aegean syllabaries evolved from the Cretan Protolinear signary (henceforth CP), which was originally made for, and by, a conservative dialect of Sumerian (Kenanidis \& Papakitsos, 2018a; 2018b), conventionally known as Eteocretan (Kenanidis, 1992). Regarding the former issue, seven LB syllabograms of hitherto unknown phonetic values will be presented in this paper, for further reinforcing the CP concept as the only basis to discover the original phonetic value of every LB sign. 


\section{Method}

Of all the Aegean syllabaries, LB is the one with the most numerous texts found and the best-studied signary that remains still in the focus of archaeolinguistics (Melena, 2014a). Nevertheless, an excessive attachment to the Greek usage of its signs, often together with a preoccupation that they were created by Greeks through the acrophonic principle and completely disregarding the similarities to the Sumerian pictography that have been noticed (Melena, 1987, p. 414; Glarner, 2002; Castleden, 2002, p. 100; Fischer, 2004, p.34; Davis, 2011, pp. 65-68), has led research to a lot of misconceptions regarding the precise phonetic use and origin of LB signs (Melena, 2014b). Undoubtedly conveying Mycenaean Greek, the pictorial origin of LB syllabograms and their original phonetic values are far better ascertained through the concept of the (Sumerian made) CP script (Kenanidis \& Papakitsos, 2015).

$\mathrm{CP}$ was both pictographic and linear. Every sign was a sketch of an object that was familiar and thereby readily recognizable by everyone in the community. The phonetic value of the sign was the whole name of the depicted object, according to the rebus principle (Fischer, 2004, pp. 34-40), which differs from the acrophonic principle. So the method to reconstruct the CP signs utilized linguistic evidence on the one hand and the contemporary cultural context on the other (Kenanidis \& Papakitsos, 2015). To recognize what was depicted by the ancient signs, it has been necessary to trace their pictorial origin through all the related Aegean syllabaries and compare it to the typical ways of representing objects in the Minoan art, while also examining the ways and habits of Sumerian pictography and vocabulary as known from Mesopotamia. Accordingly, the comparative study for each syllabogram considered four factors:

- the depicted object as reconstructed from the sign's variants in the Aegean syllabaries;

- the sign's pictorial similarity or analogy to equivalent Mesopotamian Sumerian pictograms;

- its phonetic value in the Aegean syllabaries;

- the proximity of its phonetic value to Sumerian words that denote the depicted object or some directly related concept.

The application of this methodology resulted in identifying the phonetic value of every sign with a monosyllabic (rarely disyllabic) Eteocretan (Archaic Sumerian) word that named the depicted object. Accordingly, seven LB syllabograms of hitherto unknown or very dubious phonetic value will be presented, for the first time to nonGreek-speaking readers, in the next section.

\section{Results}

In the following presentation of LB syllabograms, the main reference for Sumerian vocabulary is the Pennsylvania Sumerian Dictionary of the University of Pennsylvania, abbreviated as "PSD" (Note 1). In addition, the Electronic Text Corpus of Sumerian Literature (ETCSL) is used (Note 2). The images in the figures below have been retrieved from:

- the digital archives of the French School of Athens;

- the Cuneiform Digital Library Initiative (CDLI), where all the used images of pre-Cuneiform signs came from (Note 3);

- $\quad$ the ATU signs came from Falkenstein (1936);

- the images for LB came from Ventris \& Chadwick (1953), unless otherwise stated.

- Finally, the Sumerian phonological rules mentioned in parentheses (e.g., "rule 5.0.13, p. 35") refer to the specified page in Kenanidis \& Papakitsos (2013).

Before proceeding further, the reader should be reminded of a well-known Sumerian phonotactics feature, applying to all dialects including Eteocretan: the final consonant of a word was silenced, unless the word-stem was followed by a vowel (Kenanidis \& Papakitsos, 2015, p. 336). This is indicated here by enclosing the word's coda consonant in parentheses.

\subsection{Syllabogram "ye"}

Syllabogram LB 83 (Fig. 1a) is also found in LCG (Fig. 1b) with similar but simplified forms (turning "y" to "m" was very common in Sumerian: rule 5.0.13, p. 35). This sign depicted a human leg in profile or a pair of legs in front view. The word for a leg was the same as for a pair of legs, as generally the grammatical number in Sumerian was not expressed unless when important, especially for object names. This linguistic feature is also witnessed by $\mathrm{CH}$, where most inscriptions depict one leg (Fig. 1d) but others a pair of them (Fig. 1c) for the same syllable (namely, "ye"). In the LB and LCG sign (Fig. 1a and Fig. 1b respectively), the lower part of the body was summarily indicated above the leg(s). 
"Leg(s)" in Sumerian Cuneiform were written with "GÌR", which was glossed "yìri" and "me.ri" in Emesal (the feminine sociolect of Sumerian), being a proof that the initial consonant was originally $\mathrm{n}$ - (rule 5.0.13, p. 35). To be precise, legs were "ye(r)" in Sumerian, so this syllabogram recalled the word "ye(r)" and thus syllable "ne".

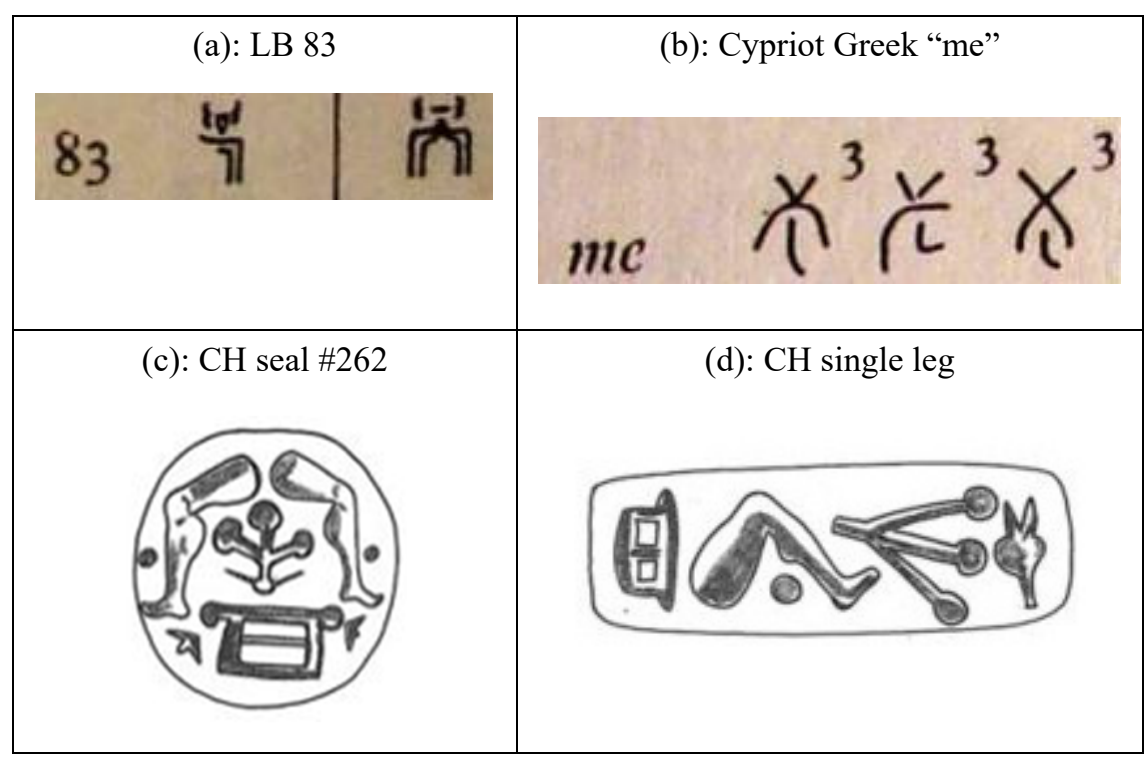

Figure 1. Syllabograms for leg(s)

This syllabogram is very important in the surviving inscriptions of $\mathrm{CH}$ (Fig. 1c-d), where the most common word is "denej" ("god"), as "dener-" was usually pronounced (rule 5.0.33, p. 37). Sometimes the word appears alone as in Fig. 1c, where it is read "de-ne-i" (= denej) or with a suffix as in Fig. 1d, where it is read "de-ne-i-du" from left to right. This syllabogram was rare in LB, because " $\mathrm{n}$ " is not a Greek phoneme, but the " $\mathrm{n}$ " in "ne" was sometimes palatalized, as it is until today in some Greek dialects. So the ancient scribes heard a Greek syllable /ne/, which they rendered by using the syllabogram "ye" (Kenanidis, 2013, p. 63).

\subsection{Syllabogram " $h u$ "}

Hu" was a rare syllabogram in LB (Fig. 2a) and even rarer in LA (AB 49), where it was found only twice (Fig. $2 \mathrm{~b}, \mathrm{c})$. The rareness of the sign indicates that it rendered a rare syllable, yet it approximated something that could be pronounced in Mycenaean Greek and in the language of the extant LA tablets. Please note that " $\mathrm{h}$ " is conventionally used for Sumerian and Akkadian "h" (i.e. /x/); / $/$ was not a Greek sound in Mycenaean times, but the sign for $/ \mathrm{xu} /$ could be used sometimes to approximate $\mathrm{Greek} / \mathrm{hu} /$.

A strong indication for the sign's phonetic value is the LCG non-Paphian " $u$ " (Fig. 1d), which is evidently a simplification of the LA form in Fig. 1c. It is suspected that this non-Paphian " $u$ " was originally used for the Greek /hu/, which was probably more common than a plain "u", if it is only reminded that "u-" was always "hu-" at the beginning of Greek words (Kenanidis, 2013, pp. 153-154).

It is easy to find what the "hu" sign depicted, because it is a variation of the LB ideogram 162 (Fig. 2e); some forms of it depict a panoply and others a tunic (often incorporating syllabograms to specify the type of tunic). In the same manner, LB ideogram 163 (Fig. 2f) represents a panoply, with a helmet added.

The panoply was named by a Sumerian word meaning basically "to embrace", therefore "human chest", "hug", "protection": it was the word "úr" ("ur 2 "). The word "ur 2 ", with these meanings mentioned, is well documented in Sumerian proverbs (Gordon, 1959), while it is also found in a PSD entry:

- $\quad$ wr. gur 21 ; kuš buru $4{ }^{\text {mušen; }}$; ur $_{2}$ "shield".

In Cuneiform transliteration, "e”" (like all superscripts) was only a determinative with "ur." (classifying but not pronounced sign), so pronounced only "ur. " that is probably /hur/ (rule 5.0.27, p. 37), meaning not a shield but a panoply. The same word in a slightly different use was "ur 3 ", translated by Akkadian edèlu (= to shut, bolt) and kidinnu (= protection, aegis), being the same as the verb meanings: "to enclose, secure, safeguard". This is exactly what the panoply does: it protects by enclosing the vital parts of the body. 


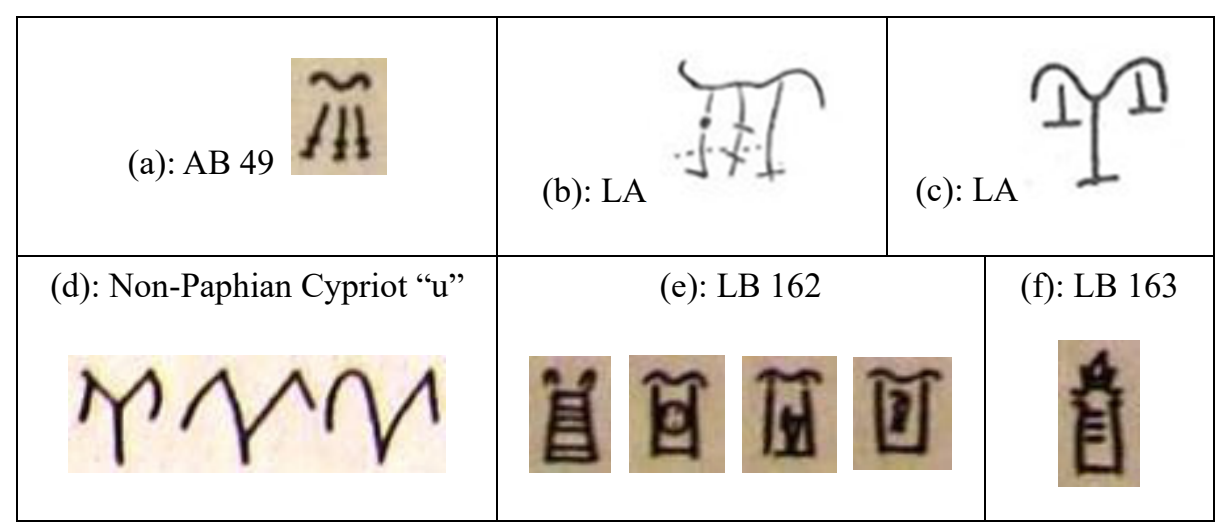

Figure 2. Signs for panoply

So, this syllabogram that depicted a panoply could be immediately recognized by the Eteocretans as "hu(r)", thus recalling the syllable "hu" (Kenanidis, 2013, p. 154).

\subsection{Syllabogram "ju"}

This is syllabogram LB 22 (Fig. 3a), much more used as an ideogram for billy-goats (Fig. 3b), nanny -goats (Fig. 3c) or goats in general (Fig. 3d). In LA (Fig. 3e) it is equally rare as a syllabogram, more corrupted from the original image and with some forms wrongly classified as AB 21 (Kenanidis, 2013, p. 145).

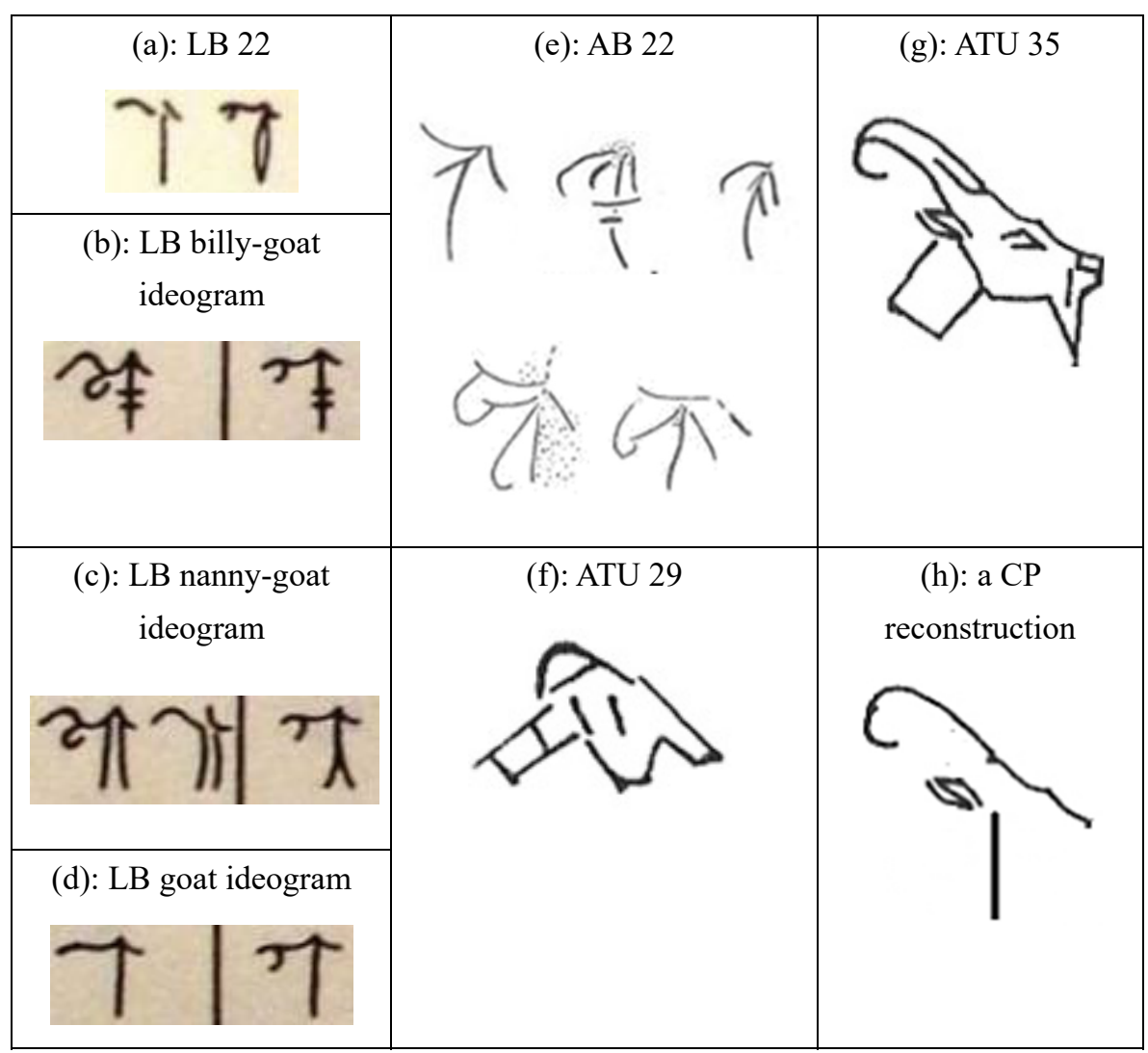

Figure 3. Signs for goat

In Sumerian pre-Cuneiform, the same sign is found as ATU 29 (Fig. 3f) and a really well written form of the same is ATU 35 (Fig. 3g), which sets the model after which the CP form was shaped (Fig. 3h), retaining only the most basic recognizable lines, as CP usually did (Kenanidis, 2013, p. 146): it was only two or three lines giving the 
impression of the face outline, ear and neck, and those were still enough because people were quite familiar with the image of a goat. "Goat" in Archaic Sumerian was "jud", attested in Cuneiform as "ud 5 " ("j" is almost never read in Cuneiform today) and in later times as "uz3" (rule 5.0.31, p. 37), being a common case of spirantization.

In the conservative Eteocretan dialect of Sumerian, the word remained "ju(d)", so whenever the Eteocretans saw this CP syllabogram, they could recognize a "ju(d)" (goat), thus recalling the syllable "ju" (Kenanidis, 2013, p. 147).

\subsection{Syllabogram "ni"}

The LB signs 34 (Fig. 4a) and 35 (Fig. 4b) are today unanimously recognized as variants of only one syllabogram (Melena, 2014c, p. 208) and its phonetic value remains totally obscure to the scientific community until today. This syllabogram has been found in LA too as AB 34 (Fig. 4c).

It can be easily seen in Fig. 4a that this sign depicts the moon (especially the $3^{\text {rd }}$ variant from left), but in such a way that it could be also taken as an image of a threaded gem. Even today, a shape like that of the letter $\mathrm{C}$ is called "lunate" (namely, reminiscent of a crescent). Most of the CP scribes though drew this sign in such a way as to incorporate a complete little circle together with the crescent shape, so reminding the reader of the round shape of the moon too and at the same time the sign's shape referred to a threaded gem. They drew it so, because in the Eteocretan (conservative Sumerian) dialect the same word could refer to both the moon and shiny gems. That word was originally */nir/ and it became "nir" in Eteocretan Sumerian, while other dialects show a "š-" $(/ \mathrm{g} /$ or $/ \mathrm{6} /)$ that came from $/ \mathrm{n} /$ and/or a $/ \mathrm{y} /$ that came from -i- (Kenanidis, 2013, p. 89). This means that the LB 34-35 sign was used for "ni" in LB and in CP, but the scientific community has not even suspected this (Melena, 2014c), because it is generally believed that LB "ni" was the LB 30 sign (Kenanidis \& Papakitsos, 2015, p. 342). It is not suspected that LB 30 was not really "ni", but the CP "yi" that was used for Mycenaean Greek [ni], because Greek -n- was usually palatalized before $-\mathrm{i}$ (see also sign " $\mathrm{ye}$ " in subsection 3.1). In some special environments (beginning of words or after certain consonants) where Greek "ni" retained a dental/alveolar "n", then that "ni" was written with LB 34-35.

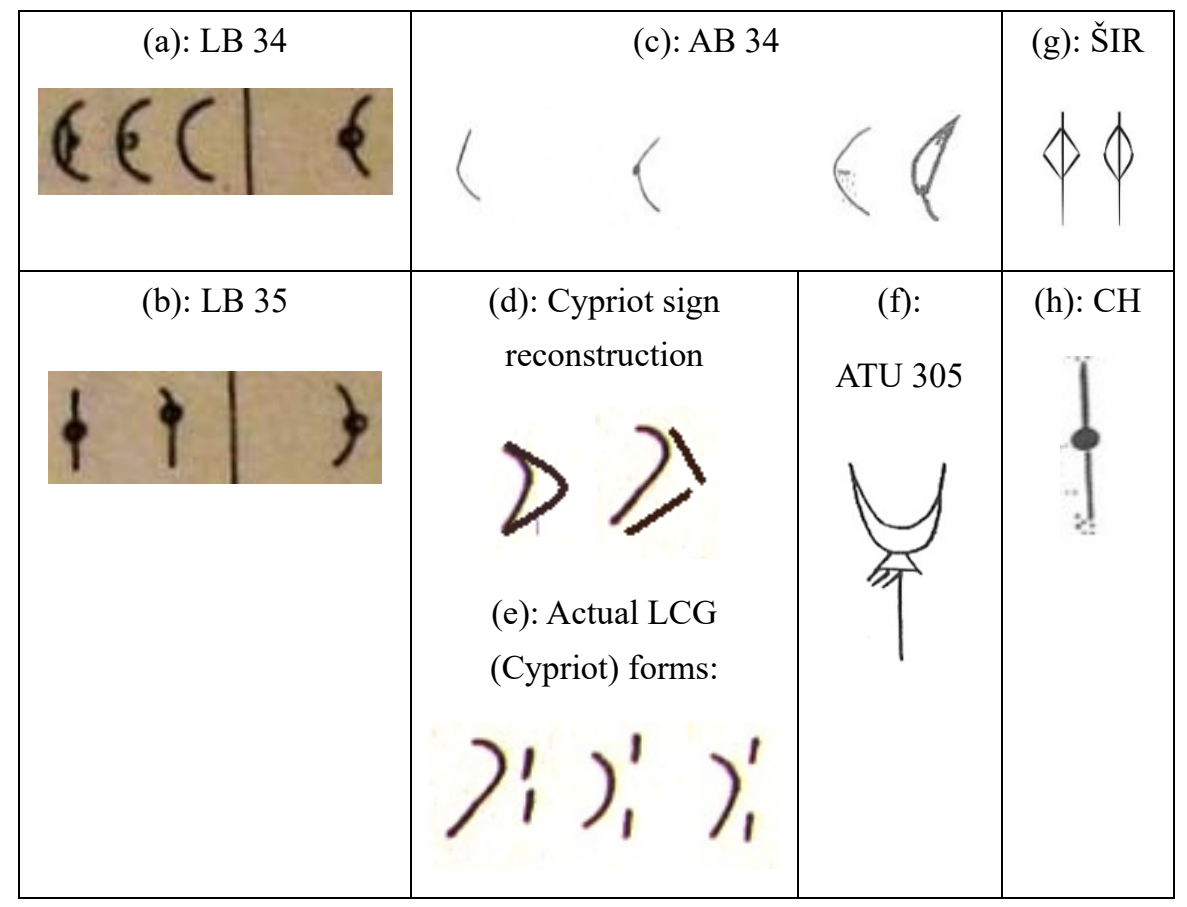

Figure 4. Signs for "moon" and "gem"

All these are sharply contrasted to the traditional and mainstream research (Melena, 2014c) which, until today, only suspects that LB 34-35 is another kind of "a" to be named "a $\mathrm{a}_{5}$ " " $\mathrm{a}_{2}$ " being LB 25 , "as" used for LB 43 and "a4" for LB 85). More recently, "ai 2 " has been suggested for LB 34-35, a guess for its phonetic value being "hai" (Melena, 2014c). This alleged relation to "a" or "ai" is only based on the fact that a word *34-ke-u was found once on a tablet and that *34-ke-u was supposed to be the same word as $\mathrm{a}_{3}-\mathrm{ke}-\mathrm{u}$, found on another tablet written by the same hand (scribe), while in fact *34-ke-u (ni-ke-u) and az-ke-u were two different words with totally different stems and meanings. 
The phonetic value "ni" fits perfectly in all the words where LB 34-35 was found. For brevity, we shall mention only the word *34-ka-te-re and *34-ke-te-si, which (with LB 34-35 = ni) makes excellent sense as nīkātēres

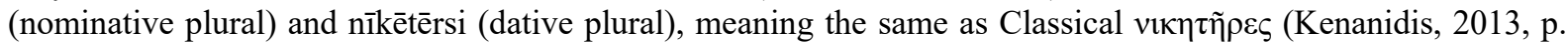
87): "the deities that cause/grant victory" (offerings to them are recorded on those tablets). Any possible remaining doubt for the phonetic value of LB 34-35 (= "ni") could be completely cleared by observing that the moon sign is also used in LGC for "nu" (Fig. 4e), derived from the Cypriot Protolinear/ny/ (Fig. 4d; a frequent change of /i/ to $/ \mathrm{y} /$ : rule 5.0.4, p. 34). It is shown how the original crescent shape (Fig. 4d) was, over time, turned into the LGC form (Fig. 4e) for easier writing on hard material.

Tracing the word for moon and gem in Mesopotamian Sumerian has been a lengthy and complicated investigation, made difficult by the changes of sound and meaning in Cuneiform Sumerian, which are made even more problematic because of the notorious inaccuracy of the Cuneiform script as it is known today. Briefly, a word for the moon was "šur"/6yr/, suffixed as "šurug"/6yryk/, originating from *ñir/nir/ (rules 5.0.4, p. 34 and 5.0.30, p. 37). There was also a word for the moon and the moonlight "nu 11 " /ny/, translated in several ancient dictionary entries by the Akkadian "nu-u $u_{2}-r u$ " (nüru being a well-known Semitic word for "light"). Then, a sacred banner called "šu-nir" is depicted by ATU 305 (Fig. 4f), showing the shape of the moon quite similar to the crescent as it figures on the top of mosques until today. From the same root/nir/ was ŠIR, being the name of the pre-Cuneiform sign (Fig. 4g) depicting a threaded pearl or another gem. The threaded gem sign is also explicit in CH (Fig. 4h).

Eteocretan, being the most conservative documented dialect of Sumerian, kept the word for "moon" and "gem" as "ni(r)", so this sign brought to their mind the syllable "ni" (Kenanidis, 2013, p. 89).

\subsection{Syllabogram "qu"}

All ancient languages (and many modern ones) show a contrast between velar (or relatively back) consonants versus palatals (or relatively front) consonants, the former being represented by "q", "g" and the latter by "k", "c" ("q", "k" are plain and "g", "c" emphatic or voiced) in all of our works (e.g., Kenanidis, 1992; 2013; Kenanidis \& Papakitsos, 2015; 2017a; 2018a). Since the first publication on the decipherment of LB (Ventris \& Chadwick, 1953), "q" and "k" in transliteration serve to show this distinction well. However, sometime around 1970, this understanding was contaminated by the misconception that "q" in LB stands only for an added labialization ("w") with no other difference between " $q$ " and " $k$ " and consequently researchers wrongly think that there could be no "qu" in LB, because "qu" would be the same as "ku" (Kenanidis, 2013, p. 131). In fact, there was also a "qu" in $\mathrm{CP}$, because the difference was not a labialization but the articulatory position being velar for "q" and palatal for "k". Mycenaean Greek had the same distinction, so LB also included this sign (LB 47) for "qu" (Fig. 5a). The same sign (more simplified of course) was used for "ku" (then indifferently velar of palatal) in LCG (Fig. 5b).

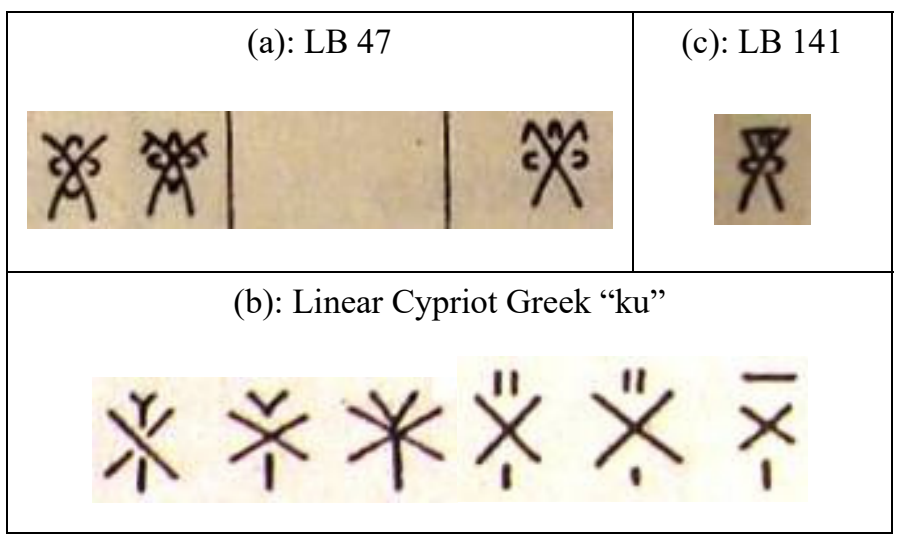

Figure 5. Syllabograms for metal

What was depicted by this syllabogram is known with certainty, because it was identical to LB ideogram 141 (Fig. 5c), which is usually interpreted as an ingot of gold, but in fact it depicted an ingot of any valuable metal, mostly silver. Silver was much more common than gold and there was no other ideogram for silver, which was the main form of money for the ancients. In ancient Greek, Sumerian, Akkadian and other Semitic languages, in Latin, as in modern French too and in old Turkic, the word for silver also means "money, cash". The word for metal in Cuneiform Sumerian is:

- $\quad$ wr. kug ( $\mathrm{ku}_{3}$ ) "metal, silver; (to be) bright, shiny" (PSD); kug = precious metal (ETCSL). 
This word was found 3,841 times without any affixation. The instances of affixation are scarce for proving the exact nature of the final consonant, which appears as -g but it could, and must have been, a $-\mathrm{n}$. There are strong evidence that in old Sumerian (early $3^{\text {rd }}$ millennium BCE) the word was "kup" that became "qup" in Crete (rule 5.0.8, p. 35) and "kuy" in Mesopotamia (rule 5.0.15, p. 35). So, on seeing this syllabogram, every Eteocretan could recognize "metal", especially "a silver ingot, cash" named "qu(p)", thus recalling the syllable "qu" (Kenanidis, 2013, p. 132).

\subsection{Syllabogram "si $i$ "}

The "ši" of CP was used in LB (Fig. 6a) for the very rare Ancient Greek syllable "zi". It depicted a type of fishing net, which was called "šiš". This word in Mesopotamia and Cyprus became "šuš" / Cuneiform Sumerian (ETCSL) it is found as "să̌u $_{2}$-uš-gal" ("gal" = large; "sa" is a determinative, unpronounced but classifying sign, indicating that the word is related to yarns or nets; the noun was pronounced "šu 2 -uš" /6y6/). The same in pre-Cuneiform is probably ATU 309 (Fig. 6b). The word was culturally so important that it was borrowed into Akkadian as šuškallu(m). The word was used in Cypriot Protolinear for "šy"/øy/, hence in Paphian LCG for "jo" (Fig. 6c).

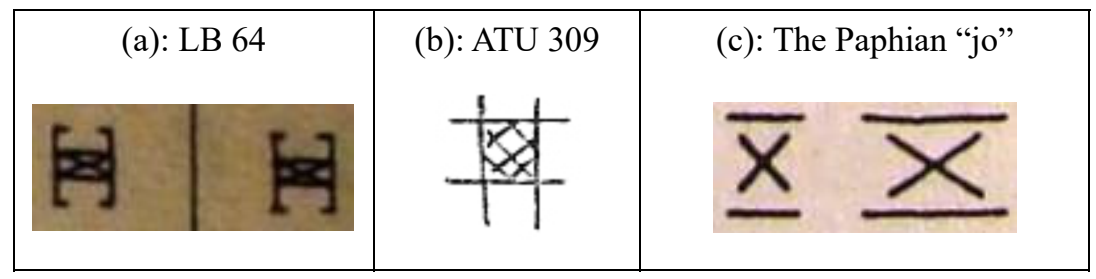

Figure 6. Signs for (a type of) fishing net

On seeing this syllabogram, the Eteocretans could immediately recognize that kind of fishing net, named "ši( $\breve{s})$ ", so recalling the syllable "ši" (Kenanidis, 2013, p. 101).

\subsection{Syllabogram "šu”}

This syllabogram is also rare in LB (Fig. 7a), but unlike the other syllabograms discussed in this paper, this one is rightfully suspected to represent Mycenaean Greek "zu", as it is found where "zu" is expected in well-known Greek words, e.g. "zugos" (yoke). There is no certain occurrence of this sign in LA. Because of its shape being so simple, its pictorial origin is not so easy to be recognized, but the scribes drew it always aslant to avoid any confusion with female genitals (vertical) or an eye (horizontal).

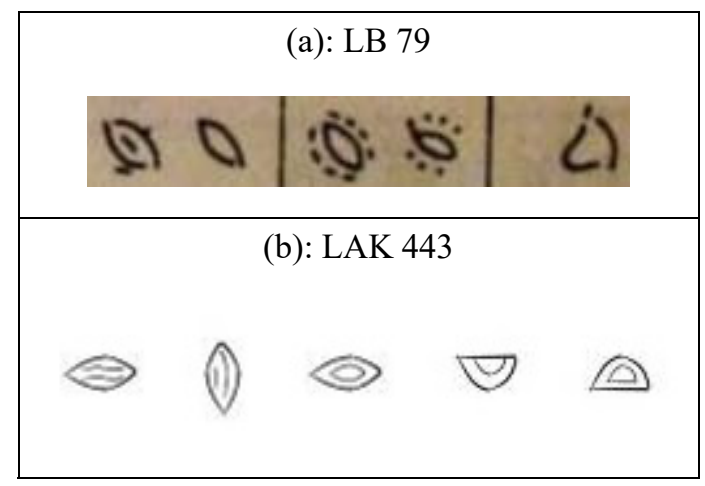

Figure 7. Signs for "interior"

The same sign is one of the most frequent in Cuneiform and pre-Cuneiform (Fig. 7b), because it stood for the word that means "inside". When referring to the body, it meant any internal organ like the stomach and womb, but especially the heart. With many metaphorical uses, it also meant the "interior" (i.e., the inner meaning) of dreams or of songs' lyrics. It was named "šag," or "ša”" / $\mathrm{cr}(\mathrm{k}) /$ in Cuneiform Sumerian, which was "šu(k)" / $\mathrm{cu}(\mathrm{k}) /$ about the $3^{\text {rd }}$ millennium BCE (rule 5.0.1, p. 34) and it was retained as "šu(q)" $(/ 6 u(k) /$ with non-palatalized $/ \mathrm{k} /$ ) in the Eteocretan dialect (rule 5.0.2, p. 34). 
So, on seeing this syllabogram, Eteocretans could recognize "the interior of the body or anything else" named "šu(q)", thus recalling the syllable "šu" (Kenanidis, 2013, p. 155).

\section{Conclusion}

This study is based on the concept of Cretan Protolinear (CP) syllabary, being the Sumerian-made script that all the Bronze Age Aegean scripts evolved from. It has been demonstrated that the phonetic value of seven LB syllabograms, hitherto regarded to be of unknown phonetic use, can be ascertained through the concept of CP. Namely, each sign's phonetic value is identified with the Eteocretan name of the object depicted by this sign. Therefore, more light is shed on the linguistic ancestry of the Aegean syllabaries and the process for their creation (Kenanidis \& Papakitsos, 2018a, p. 47).

\section{Acknowledgments}

The authors would like to express their thankfulness to the French School of Athens. Its digital archives greatly facilitated the research presented here. Also, this work would be quite inferior if there was not the Cuneiform Digital Library Initiative (CDLI). Even the main dictionary for Sumerian today (the PSD) is available at the CDLI's tools webpage.

\section{References}

Castleden, R. (2002). Minoans: Life in Bronze Age Crete. London/New York: Routledge.

Davis, B. (2010). Introduction to the Aegean Pre-Alphabetic Scripts. KUBABA, 1, 38-61. Retrieved from http://www.fcsh.unl.pt/kubaba/KUBABA/kubaba_1_2010.html

Davis, B. (2011). Cypro-Minoan in Philistia?. KUBABA, 2, 40-74. Retrieved from http://www.fcsh.unl.pt/kubaba/KUBABA/ k_2_2011_texts/DAVIS 2011 - Cypro-Minoan in Philistia.pdf

Falkenstein, A. (1936). Archaische Texte aus Uruk (ATU). Ausgrabungen der Deutschen Forschungsgemeinschaft in Uruk - Warka (volume II). Berlin.

Fischer, S. R. (2004). History of Writing. London: Reaktion Books.

Glarner, H. (2002). Sumerische Schriftzeichen in Der Linear A. Kadmos, 41(s1), 121-122. https://doi.org/10.1515/kadm.2002.41.s1.121

Gordon, E. I. (1959). Sumerian Proverbs. Philadelphia: University of Pennsylvania, University Museum (Reprinted in 1968, with a chapter by Thorkild Jakobsen, New York: Greenwood Press). https://doi.org/10.9783/9781512816372

Hooker, J. T. (2011). Introduction to Linear B (2 $2^{\text {nd }}$ reprint). Athens: MIET (in Greek).

Judson, A.P. (2017). The Decipherment: People, Process, Challenges. In Y. Galanakis, A. Christophilopoulou \& J. Grime (eds.), Codebreakers and Groundbreakers (pp. 15-29). Cambridge: The Fitzwilliam Museum.

Kenanidis, I. (1992). Eteokreetes Megaleetores. Athens: National Library of Greece (in Greek).

Kenanidis, I. (2013). Historical and Linguistic Studies: cwepeker.doc. Kavala, Greece: E.P. Lazidou (in Greek).

Kenanidis, I. K. (2016). A 17th c. BC Minoan Votive Double Axe (Labrys). The Arkalochori Axe and its siblings. Anistoriton Journal, In Situ 15(1), 1-20. Retrieved from http://www.anistor.gr/english/enback/2016_1s_Anistoriton.pdf

Kenanidis, I. K., \& Papakitsos, E. C. (2015). A Comparative Linguistic Study about the Sumerian Influence on the Creation of the Aegean Scripts. Scholars Journal of Arts, Humanities and Social Sciences, 3(1E), 332-346. Retrieved from http://saspjournals.com/sjahss-31/

Kenanidis, I. K., \& Papakitsos, E. C. (2017a). Linguistic and Cultural Aspects of Disyllabic Signs in the Cretan Protolinear Script. Scholars Bulletin, 3(10), 489-496. https://doi.org/10.21276/sb.2017.3.10.9

Kenanidis, I. K., \& Papakitsos, E. C. (2017b). An Interpretation of the Malia Stone Inscription in Terms of the Cretan Protolinear Script. Terra Sebus. Acta Musei Sabesiensis, 9, 43-56. Retrieved from https://www.cclbsebes.ro/muzeul-municipal-ioan-raica/terra-sebus-nr9.html

Kenanidis, I. K., \& Papakitsos, E. C. (2018a). Cretan Protolinear Script: The Sixth-Vowel Set of Syllabograms. International Linguistics Research, 1(1), 32-48. https://doi.org/10.30560/ilr.v1n1p32

Kenanidis, I. K., \& Papakitsos, E. C. (2018b). Culturally Important Objects as Signs of Cretan Protolinear Script. Humanities and Social Science Research, 1(1), 21-29. https://doi.org/10.30560/hssr.v1n1p21

Kenanidis, I., \& Papakitsos, E. C. (2013). Yet another suggestion about the origins of the Sumerian language. 
International Journal of Linguistics, 5(5), 30-44. https://doi.org/10.5296/ijl.v5i5.4107

Melena, J. L. (1987). On the Linear B Ideogrammatic Syllabogram ZE. In J. T. Killen, J. L. Melena \& J. P. Olivier (Eds.), Studies in Mycenaean and classical Greek presented to John Chadwick (pp. 389-457). Salamanca: Ediciones Universidad de Salamanca.

Melena, J. L. (2014a). Mycenaean Writing. In Y. Duhoux \& A. Morpurgo Davies (Eds.), A Companion to Linear B: Mycenaean Greek Texts and Their World (Vol. 3, pp. 1-186). Leuven: Peeters.

Melena, J. L. (2014b). Filling gaps in the basic Mycenaean syllabary. In A. Bernabé \& E. R. Luján (Eds.), Donum Mycenologicum: Mycenaean Studies in Honour of Francisco Aura Jorro (pp. 75-85). Louvain-LaNeuve/Walpole, MA: Peeters.

Melena, J. L. (2014c). Filling Gaps in the Mycenaean Linear B Additional Syllabary. The Case of Syllabogram *34. In Á. M. Fernández, B. O. Villaro, M. del Henar Velasco López and H. Z. Salamanca (Eds.), Ágalma. Ofrenda desde la Filología Clásica a Manuel García Teijeiro (pp. 207-226). Valladolid: Universidad de Valladolid. Retrieved from http://www.academia.edu/5698885/Filling_Gaps_in_the_Mycenaean_Linear_B_Additional_Syllabary_The _Case_of_Syllabogram_34

Papakitsos, E. C., \& Kenanidis, I. K. (2016). Cretan Hieroglyphics: The Ornamental and Ritual Version of the Cretan Protolinear Script. Anistoriton Journal, Essays 15(2), 1-12. Retrieved from http://www.anistor.gr/english/enback/2016_2e_Anistoriton.pdf

Steele, P.M. (2017). Other Pre-alphabetic Scripts of Crete and Cyprus. In Y. Galanakis, A. Christophilopoulou \& J. Grime (eds.), Codebreakers and Groundbreakers (pp. 45-53). Cambridge: The Fitzwilliam Museum.

Ventris, M., \& Chadwick, J. (1953). Documents in Mycenaean Greek ( $1^{\text {st }}$ Edition). Cambridge: Cambridge University.

Woudhuizen, F. C. (2016). Documents in Minoan Luwian, Semitic, and Pelasgian. Dutch Archaeological and Historical Society, Amsterdam: Publications of The Henri Frankfort Foundation.

\section{Notes}

Note 1. Available at: http://psd.museum.upenn.edu/epsd/index.html

Note 2. Available at: http://etcsl.orinst.ox.ac.uk/

Note 3. Available at: https://cdli.ucla.edu/tools/SignLists/protocuneiform/archsigns.html

\section{Copyrights}

Copyright for this article is retained by the author(s), with first publication rights granted to the journal.

This is an open-access article distributed under the terms and conditions of the Creative Commons Attribution license (http://creativecommons.org/licenses/by/4.0/). 